\title{
First report of powdery mildew caused by Erysiphe russellii on Oxalis dillenii in Korea
}

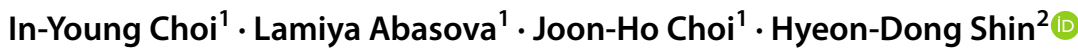

Received: 1 January 2022 / Accepted: 1 February 2022 / Published online: 8 February 2022

(c) The Author(s) under exclusive licence to Società Italiana di Patologia Vegetale (S.I.Pa.V.) 2022

Keywords Chasmothecia $\cdot$ Identification $\cdot$ Invasive plant

Oxalis dillenii Jacq. is a herbaceous plant native to North America. This plant was introduced to Korea by chance and became invasive in the natural range (Hong et al. 2016). In September 2019, several $O$. dillenii plants growing wild in Hoengseong were found infected with a powdery mildew with $100 \%$ disease incidence and followed by $70 \%$ and $100 \%$ disease incidence in June and July 2020 at two locations of Hongcheon. Symptoms of the disease were white and powdery due to the net-like mycelial mats with abundant conidiophores and conidia on the leaves, stems, and inflorescence. Three voucher specimens were deposited in the Korea University herbarium (KUS-F31151, F31804, and F31837). Hyphal appressoria were lobed and mostly solitary. Conidiophores $(n=20)$ were erect, 70-160×4-6 $\mu \mathrm{m}$, and 3-4-celled. Singly formed conidia ( $n=20)$ were oval to fusiform, $24-42 \times 14-18 \mu \mathrm{m}$, devoid of fibrosin bodies, and produced germ tubes on the perihilar position. The morphological features of the fungus were consistent with those of Erysiphe russellii Clint. (Braun and Cook 2012). Chasmothecia were not observed until the infected plants died in winter. Molecular identification was performed according to the nucleotide sequences of ITS regions and $28 \mathrm{~S}$ rDNA gene amplified using ITS1-F/PM6 and PM3/TW14 primer pairs, respectively. Obtained sequences were deposited into the GenBank with accession Nos. OM033225 (534 bp), OM033226 (530 bp) for ITS and OM033227 (1028 bp) for 28S rDNA gene. BLASTN search results for ITS and 28S rDNA gene showed $100 \%$ identity with sequences LC010056 and LC009922 of E. russellii in GenBank. E. russellii has been known on several species of Oxalis including $O$. dillenii globally

Hyeon-Dong Shin

hdshin@korea.ac.kr

1 Department of Agricultural Biology, Jeonbuk National University, Jeonju 54896, Korea

2 Division of Environmental Science and Ecological Engineering, Korea University, Seoul 02841, Korea
(Farr and Rossman 2022). Although this fungus was recorded on $O$. corniculata and O. corymbosa in Korea (Farr and Rossman 2022), this is the first report of $E$. russellii on O. dillenii.

Acknowledgements This work was supported by the Korea Institute of Planning and Evaluation for Technology in Food, Agriculture and Forestry (IPET), funded by the Ministry of Agriculture, Food and Rural Affairs (MAFRA) (Project No. 320043-05).

\section{Declarations}

Informed consent The manuscript is new and not being considered elsewhere. All authors have approved the submission of this manuscript.

Conflict of interest The authors declare no conflict of interest.

\section{References}

Braun U, Cook RTA (2012) Taxonomic manual of the Erysiphales (Powdery Mildews). CBS Biodiversity Series No. 11. CBS, Utrecht, The Netherlands

Farr DF, Rossman AY (2022) Fungal databases, U.S. National Fungus Collections, ARS, USDA. Accessed 2 Jan 2022

Hong JK, Kim J, Kim JH, Choi JE, Kim JS (2016) Two unrecorded alien plants of South Korea: Lepidium pinnatifidum Ledeb. (Brassicaceae) and Oxalis dillenii Jacq. (Oxalideaceae). Korean J Plant Taxon 46:331-335

Publisher's Note Springer Nature remains neutral with regard to jurisdictional claims in published maps and institutional affiliations. 